\title{
Delivering too much, too little or off target-possible consequences of differences in perceptions on agricultural advisory services
}

\author{
Jannica Krafft ${ }^{1}$ (I) Jenny Höckert ${ }^{2} \cdot$ Magnus Ljung $^{2} \cdot$ Sara Lundberg ${ }^{3} \cdot$ Christina Lunner Kolstrup $^{4}$
}

Accepted: 21 June 2021 / Published online: 9 July 2021

(c) The Author(s) 2021

\begin{abstract}
Advisory services are considered to play an important role in the development of competitiveness and sustainability in agriculture. Advisory services have been studied at policy level, structural level and within case studies, but there is still restricted knowledge about advisors' and farmers' view on advisory services in general. This paper presents the views of Swedish advisors and farmers on advisory services. In a survey-based study, perceptions of farm advisors and full-time farmers in commercial Swedish agriculture on advisory services were identified and statistically analysed, comparing differences between and within the groups. The results are structured around three main themes; motives for a farmer using or not using advisory services, preferred approach by the advisor and future demands on advisory services and their importance today. Possible consequences of differences in perceptions for on-farm service delivery were assessed. Similarities in perceptions on advisory services among advisors and farmers, were found in areas characterised by well-defined questions or productionrelated issues. Significant differences in perceptions of advisors and farmers emerged in less concrete areas and on topics connected to change, management and strategy. Consequences of discrepancies in perceptions are that advisors may deliver too much, too little or off target, especially when expectations on advisory services are not clearly expressed. A strong and proactive back-office supporting the advisors is needed to prevent these possible consequences.
\end{abstract}

Keywords Advisors · Farmers · Perceptions · Motives · Learning · Questionnaires

Jannica Krafft

Jannica.Krafft@vxa.se

Jenny Höckert

Jenny.Hockert@slu.se

Magnus Ljung

Magnus.Ljung@slu.se

Sara Lundberg

Sara.Lundberg@vxa.se

Christina Lunner Kolstrup

Christina.Kolstrup@slu.se

1 Department of People and Society, Swedish University of Agricultural Sciences and Växa Sverige, Torsholmsvägen 3, SE-311 50 Falkenberg, Sweden

2 Department of People and Society, National Competence Centre for Advisory Services, Swedish University of Agricultural Sciences, SLU Skara, SE-532 31, Smedjan, Skara, Sweden

3 Växa Sverige, Torsholmsvägen 3, SE-311 50 Falkenberg, Sweden

4 Department of People and Society, Swedish University of Agricultural Sciences, P.O Box 190, SE-234 22 Lomma, Sweden

\section{Introduction}

\section{Agricultural advisory service in a changing world}

Demand for advisory services is increasing because the competitive world market is a challenge for farms, as it is for most small businesses in other sectors. Although productivity in agriculture has increased in recent decades, this has not resulted in increased profitability or competitiveness, which has led to many farm businesses closing down (SOU 2014:38; Ingram and Mills 2019). There is no indication that this trend will end in the foreseeable future (Wästfelt and Eriksson 2017). To survive, small and medium-sized enterprises, often family businesses, face a growing need to find new paths and development strategies (Hajdu et al. 2020). This is an area in which farm advisors can play an important role.

Society, the agricultural sector and advisory organisations have shown differing responses to the ongoing restructuring of the agricultural sector. These responses have largely been within the framework of existing development paths, either 
through increased productivity and size rationalisation or through reinforced ambitions to develop new products and services. Efforts to increase productivity take place in many ways through existing agricultural policy, which includes measures to strengthen farmers' management skills or to implement new technologies. The development of new products and services is promoted through supportive measures for entrepreneurship (SOU 2014:38) and through conventional investment support.

Current societal trends, such as digitalisation, climate adaptation and bio-based economy, require different development strategies for agricultural businesses. Acceptance of increased heterogeneity and complexity requires a different view on the development of knowledge and skills, and therefore farmers and advisors need to adapt. This places great new demands on advisors and their organisations. However, advisory organisations tend to respond to community changes rather than being proactive (Birner et al. 2009; Prager et al. 2017). As long as this continues, advisory organisations will not be a driver for change. Over recent decades, Sweden has seen a range of new efforts by advisory organisations to increase their ability to deliver high-quality services to farmers (Höckert and Ljung 2013). On organisational level, changes include consolidation of operations within existing advisory organisations, reorganisations within and between existing advisory organisations, emergence of new platforms for collaboration (partnerships and regional innovation clusters), and strengthening of specific advisory skills using coaches, rural developers and innovation managers (Dockès et al. 2019). Developing the organisational back-office (organisational support and development) in order to improve front-office deliveries (interactions with farmers) is suggested to be an important factor for success (Labarthe and Laurent 2013). The interplay between front- and back-office work and how the advisory organisation supports changes in advisory practice puts the focus not only on how services are designed or made available to farmers, but also how service performance can be improved.

\section{Shifting from best practice to best fit in advisory services}

Previous analyses have shown that increased awareness, knowledge, participation and capacity among farmers are keys to sustainable development of agriculture (Röling and Pretty 1997; Blackmore 2010). Farmers make strategic and operating decisions that bridge theory and practice, balancing a desirable future with what is feasible. It is often emphasised that advisors need to know the farmer, not just the issue at hand, and thus move beyond the role of expert and build relationships (Mills et al. 2017). The importance of advisors' ability to understand farmers and to prove themselves reliable, competent, credible, impartial and trustworthy has long been acknowledged (Ingram 2008). Trust has also been identified as an important factor for the credibility of advisors with advisors from a farming background or with a trusted network having more influence (Blackstock et al. 2010).

Being a farm advisor requires the ability to adapt to the situation and take on different roles, depending on the issue at hand (Klerkx and Jansen 2010; Kania et al. 2014; Dockès et al. 2019; Ingram and Mills 2019). There is no specific 'best practice' in advisory services. Advisors need to master a pool of potentially useful alternatives, depending on the situation and context (Landini 2016). In order to facilitate change, it is important that the advisor understands the individual farmer's values and norms (Mills et al. 2017), as well as their technical constraints and financial space. Andersen (2004) and Höckert and Ljung (2013) stress the importance of strengthening issues related to personal meanings and values, such as beliefs on custodianship and productivity (Mills et al. 2017). Advisors need to be aware of the different skills and competences that may come into play during an advisory encounter, where they need to be more than specialist, which can help with implementation of technical knowledge and co-create behavioural change (Andersen 2004). Advisors also need certain communication skills (Höckert and Ljung 2013). However, many farmer-advisor encounters are in short-term projects, which presents a difficulty in building trusting relationships (Mills et al. 2017). Change is not a quick fix and it is impossible for advisors to begin guiding farmers after just one farm visit-implementation that requires alterations to the organisational structure and management strategy of the farm takes time (Dockès et al. 2019). In a study of Lean Farming in Sweden, Melin and Barth (2018) concluded that even an 18-month programme is too short to achieve full immersion.

The heterogeneity within the population of farmers presents a challenge for advisory services seeking to tailor their message and methods (Dwyer et al. 2007; Feder et al. 2011; McKillop et al. 2018; Dockès et al. 2019). There is thus a need for a diverse range of advisory methods to meet the different needs and requirements of the diverse agricultural industry (Prager et al. 2017). However, there are doubts as to whether the advisory services can respond to these diverse, and sometimes contradictory, expectations (Faure et al. 2012). In order to know what changes are needed in the advisory services, we must understand how farmers perceive the current provision of advisory services and what expectations they may have, which requires a profound study of farmers. Similarly, it is important to identify the perceptions of advisors.

Farmers' motives for performing certain practices or engaging in different schemes have been examined in several studies (eg. Burton 2004; Dwyer et al. 2007; Ingram et al. 2013; Collins et al. 2016; Inman et al. 2018; Ingram and Mills 2019). However, few studies have examined farmers' 
Table 1 Sample size and number of survey responses obtained from advisors, divided by type of organisation

\begin{tabular}{llllllll}
\hline Organisation type & $\begin{array}{l}\text { Estimated number } \\
\text { of advisors, N }\end{array}$ & $\begin{array}{l}\text { Sampled } \\
\text { advisors, N }\end{array}$ & $\begin{array}{l}\text { Not working as } \\
\text { advisor, N }\end{array}$ & $\begin{array}{l}\text { Don't want to } \\
\text { participate, N }\end{array}$ & $\begin{array}{c}\text { No reply, N } \\
\text { Responses, N }\end{array}$ & $\begin{array}{l}\text { Response } \\
\text { rate, \% }\end{array}$ \\
\hline Advisors & 700 & 638 & 57 & 39 & 274 & 268 & 46 \\
Public & $>10$ & 0 & & & 296 & 220 \\
Farmer-based (FBO) & 500 & 493 & 38 & 10 & 68 & 48 \\
Private & 200 & 152 & 19 & 10 & 36 \\
\hline
\end{tabular}

motives for using external support, such as advisory services. Advisory services, in turn, have been thoroughly studied at policy level (eg. OECD 2018; EU SCAR 2019), structural level (Kania et al. 2014; Knierim et al. 2017) and within case studies (eg. Andersen 2004; Mills et al. 2017; Ingram and Mills 2019). However, there is still a lack of knowledge about farmers' and advisors' views on advisory services, and their contribution to business development. Matching demand and supply will require changes in both farmers' capacity to order relevant services and advisors' ability to meet expectations and change mindsets and current farm management.

The aim of this study was to identify similarities and discrepancies in perceptions among advisors and farmers on agricultural advisory services in Sweden. Based on analysis of the data and discussion of existing and new findings, the consequences of possible differences in perceptions on onfarm delivery of services and the implications for advisory organisations were assessed.

\section{Material and methods}

\section{An overview of the Swedish agricultural advisory system}

The Swedish agricultural advisory system has many similarities with those in other countries within the European Union, with both commercial and publicly funded advisory services (Kania et al. 2014; Nordlund and Norrby 2021; Yngwe 2014). Within the commercial advisory services in Sweden there are four main actors: Gård \& Djurhälsan, Ludvig \& Co, the Rural Economy and Agricultural Societies and Växa Sverige. These employ most of the advisors in Sweden, cover the whole country and together reach a majority of Swedish full-time farmers. They overlap to some extent in their offer, but they all have different main focus areas. The Rural Economy and Agricultural Societies and Växa Sverige are farmer-based organisations (FBO), while Gård \& Djurhälsan and Ludvig \& Co are private, but minorityowned by FBOs. Besides these, there are over 50 minor local and commercial advisory organisations, of which the majority are private and some are FBOs. There are no coherent official records comprising all individual advisors in Sweden, but estimated numbers based on information from websites and personal contacts are provided in Table 1.

The majority of the advisory services provided are related to production, animal health or financial services, such as bookkeeping and financial statements. The advisory services are often a type of subscription agreement on a specific service, but single assignments and shorter projects are also common. The advisory services are paid for by farmers per hour or in packages based on farm size (hectares). Publicly funded services focus on public goods such as animal welfare, environmental measures and rural development. The majority of the publicly funded services are procured and delivered by the FBOs or private actors to the farmers free of charge or subsidised. In some regions, the County Administration Board provides these services, using publicly funded advisors. In addition, advisory services provided by organisations selling production inputs to farmers are increasing, but these organisations were not included in the present analysis.

\section{Selection of respondents}

The aim was for the questionnaire to reach all advisors working with farmers in commercial agriculture. Contact information for individual advisors surveyed in this study was obtained from websites of the different advisory service organisations, small private firms and sole-operating advisors, of which all identified were contacted. One of the largest advisory firms does not make advisors' contact information accessible on its website. The head of its advisory group was approached, but declined to participate due to lack of time.

The sample of farmers surveyed was drawn from "Holdings in the Farm Register and Business Register", which include all Swedish businesses with land ( $>2$ ha arable land or $>5$ ha farm land), animal husbandry or horticulture, supplied by Statistics Sweden in June 2017. This comprised 62094 businesses registered in 2016. The aim was to reach full-time farmers in commercial agriculture and therefore the number was reduced by excluding farms and business with less than 1600 yearly working hours, businesses producing flowers, fruits and berries and nurseries. The final list 
Table 2 Sample size and number of survey responses obtained from farmers also divided by type of production

\begin{tabular}{|c|c|c|c|c|c|c|c|c|c|}
\hline Production & $\begin{array}{l}\text { Finite } \\
\text { population, } \\
\mathrm{N}\end{array}$ & $\begin{array}{l}\text { Finite } \\
\text { population, } \\
\%\end{array}$ & Sample, N & Sample, $\%$ & Responses, $\mathrm{N}$ & $\begin{array}{l}\text { Blank or } \\
\text { incomplete, } \\
\mathrm{N}\end{array}$ & Complete, $\mathrm{N}$ & Complete, $\%$ & $\begin{array}{l}\text { Response } \\
\text { rate, \% }\end{array}$ \\
\hline Farmers & 14,352 & & 2008 & & 727 & 142 & 586 & & 29 \\
\hline Arable & 4343 & 30 & 601 & 30 & 253 & 51 & 202 & 35 & 34 \\
\hline Beef & 5350 & 37 & 700 & 35 & 244 & 46 & 198 & 34 & 28 \\
\hline Dairy & 3264 & 23 & 405 & 20 & 133 & 28 & 105 & 18 & 26 \\
\hline Pigs & 617 & 4 & 102 & 5 & 37 & 1 & 36 & 6 & 35 \\
\hline Poultry & 217 & 2 & 100 & 5 & 33 & 9 & 24 & 4 & 24 \\
\hline Sheep & 561 & 4 & 100 & 5 & 27 & 6 & 21 & 4 & 21 \\
\hline
\end{tabular}

of possible respondents comprised 14,352 farm businesses (Table 2). A proportionally stratified random sample of 2008 farmers was created, to ensure that the respondents were representative of farmers in Sweden, reflecting the range of different production types. The production types chosen were arable, dairy, beef, poultry, pigs and sheep (Table 2).

\section{Sample size and response rate}

The sample of advisors approached to participate in the survey comprised 638 advisors, of which 364 replied. Fiftyseven of those responding stated that they were not currently working as agricultural advisors. Thirty-nine advisors did not want to participate, due to lack of time or lack of experience (recently started working as an advisor). Complete responses for analysis were obtained from 268 advisors (response rate $46 \%$ ) (Table 1).

A total of 727 responses were received from farmers, of which 586 were completed to at least $70 \%$ and considered acceptable for analysis (29\% response rate) (Table 2). The distribution of replies within the different production sectors was representative of the Swedish population of farming enterprises (Table 2).

\section{Socio-demographic characteristics of advisors and farmers}

\section{Advisors}

A majority (66\%) of advisors who completed the questionnaire were female. The age of advisors ranged from 24 to 68 years (mean 44 years), and the average experience of work as an advisor was 12 years, ranging from just a few months to 44 years. The majority of the advisors worked fulltime as advisors (53\%), while the rest $(47 \%)$ worked as advisors as part of other employment. Of the advisors, $50 \%$ had a Master's degree in agriculture, mainly within crop science $(21 \%)$ or animal science (17\%), and around a quarter $(24 \%)$ had a Bachelor's degree in agriculture and rural management. The rest had a varying background, with veterinary science being the largest group (7\%).

Most of the advisory services delivered by the advisors were paid for by the farmers. A majority (85\%) of the advisors conducted subsidised advisory services at less than $25 \%$ of their total budget, while only $2 \%$ of the advisors carried out more than $75 \%$ of subsided work.

\section{Farmers}

Of the total of 586 farmers participating in the study, the majority were male $(91 \%)$. The mean age of participating farmers ranged from 25 to 92 years (mean 57 years). For $69 \%$ of the farmers, the highest level of education was elementary school or high school, while $31 \%$ had a university degree. More than half of the respondents (60\%) had an agricultural qualification. More than one-third of the farms were situated in a plain district (38\%), 30\% in a forest district and $32 \%$ in a central district. Three-quarters $(75 \%)$ of the farms were run conventionally, $18 \%$ organically and $6 \%$ of the farms had both conventional and organic farming. Farm size varied from 0 ha to 2800 ha, with an average size of $181 \mathrm{ha}$. The farms with 0 ha of land ( 8 in total) had poultry or pig production. The number of full-time employed workers on the farms varied from 0 to 36 (median 1.3). The yearly financial turnover varied from 4000 EUR to 4,000,000 EUR (median 200,000 EUR).

The farmers spent an average of 1700 EUR per year on advisory services. The dairy farmers and pig farmers had the highest mean expenditure (2700 EUR), followed by poultry farmers (2400 EUR) and arable farmers (1800 EUR). The majority of the respondents (88\%) used advisory services of some sort (including free advisory services provided by sales personnel or services publicly subsidised).

From the characterisation of the group of farmers above, with the turn-over span and respondents with an age well past retirement, it can be seen that the questionnaire also reached farmers not included in the target group. This can be explained, at least in part, by a change in production since 
the time of inclusion in the register. All responses were included in the analysis. When comparing our sample with the socio-demographics of all farmers in Sweden based on the official database from Statistics Sweden, our sample was found to be representative (SJV 2018).

\section{Questionnaires}

Aiming to identify generalisable differences in perceptions on advisory services between advisors and farmers, respectively, questionnaires were chosen as the data collection method, since it permits a large number of respondents to be surveyed. The questionnaires were pre-tested in a pilot study and then distributed throughout the whole of Sweden in 2019, one directed to advisors and the other to farmers. The short time frame in which the questionnaires were distributed and the mainly similar questions they contained allowed comparison between the two respondent groups.

Both questionnaires had a similar structure. The first part consisted of questions on background factors relevant for both groups, such as gender, age and education. There were also questions on additional background factors, relevant for each group. For example, the advisors were asked questions about their employer, years of working as an advisor, areas of expertise and extent of subsidised advisory work. The farmers were asked questions about the farm, such as types of production, farm size, number of employees and turnover. The farmer questionnaire also had a section about their current use of advisory services.

The second part of the questionnaire consisted of statements about advisory services related to market and supply, routines and tools, and the farmer's requirements on the advisor and advisory services. The statements and questions were chosen in order to capture the perceived benefit and demands on advisory services. The questions, statements and answer options in the questionnaires had their origin in and corresponded to the ongoing discourse in advisory services in Sweden. The advisor questionnaire also included an additional section about back-office support. In both cases, the questions in this part were formulated as statements using a 7-point Likert-type response scale with values ranging from 1 to 7 (Malhotra 2006), where 1 represents strongly disagree or not at all important and 7 represents strongly agree or very important (4 represents either/or). The questionnaires also included the possibility for comments, allowing the respondents to elaborate upon their chosen responses.

The questionnaire to advisors was internet-based, distributed by link in e-mail and comprised 38 questions. The questionnaire was open between May 5 and June 112019 and included three reminders. Netigate was used to administer the questionnaire electronically.
The questionnaire to farmers was dispatched by mail in January 2019 and consisted of 45 questions. This was followed by a reminder postcard after three weeks. Further reminders were not distributed as enough responses for $95 \%$ confidence interval had been reached. Replies arrived until August 2019. Two lottery tickets (worth six EUR) were sent to farmers who completed the questionnaire.

\section{Data analysis}

When comparing farmers and advisors, they were analysed as two groups, without considering socio-demographic factors, production specialisation, etc. However, the variation within each group was analysed based on gender, age and type of employer (private or FBO) for advisors and based on gender, age and type of production for farmers. Before analysing the answers with respect to age, the advisors and farmers were first grouped into quartiles, ${ }^{1}$ which differed between advisors and farmers in all cases. The sample size of farmers within each type of production was too small to achieve a confidence interval of $95 \%$. Consequently, no firm conclusions could be drawn in that area, but tendencies could be detected.

The statistical software JMP Pro 14 was used for analysis of the data once they had been imported respectively recorded in Excel. The number (N), frequency (\%), mean, median and standard deviation (sd) were calculated. In statistical analysis of the results, a t-test assuming unequal variance was used to test for similarity of mean values between the two groups (advisors and farmers), based on $t$ ratio and p-value. For comparisons within each group Wilcoxon method was used. A significance level of $p<0.05$ was applied in the analysis. Statistical testing ensured that the difference between advisors and farmers were statistically significant, and not an effect of random variations.

To illustrate the data graphically, boxplots are included in the tables of results to show the distribution of responses in the data, divided into quartiles. The box in those cases represents $50 \%$ of the responses, while the line in the box indicates the median. The lines (whiskers) extending from the box indicate the range of variation, i.e. the upper and lower quartiles. The outliers are plotted as individual points. Skewness in the responses gives a boxplot with only one box and one whisker, where the box represents $75 \%$ of responses. The scale above the boxplots shows the Likert scale from 1 to 7 .

\footnotetext{
1 Advisors: Q1 24-24, Q2 33-42, Q3 43-54 and Q4 55-68 years. Farmers Q1 24-47, Q2 48-56, Q3 57-64 and Q4 65-92 years.
} 


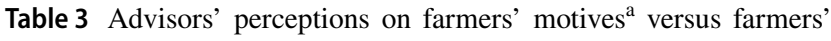
descriptions of their motives ${ }^{\mathrm{a}}$ for choosing advisory services sorted in descending order based on $t$ ratio for discrepancies between the two

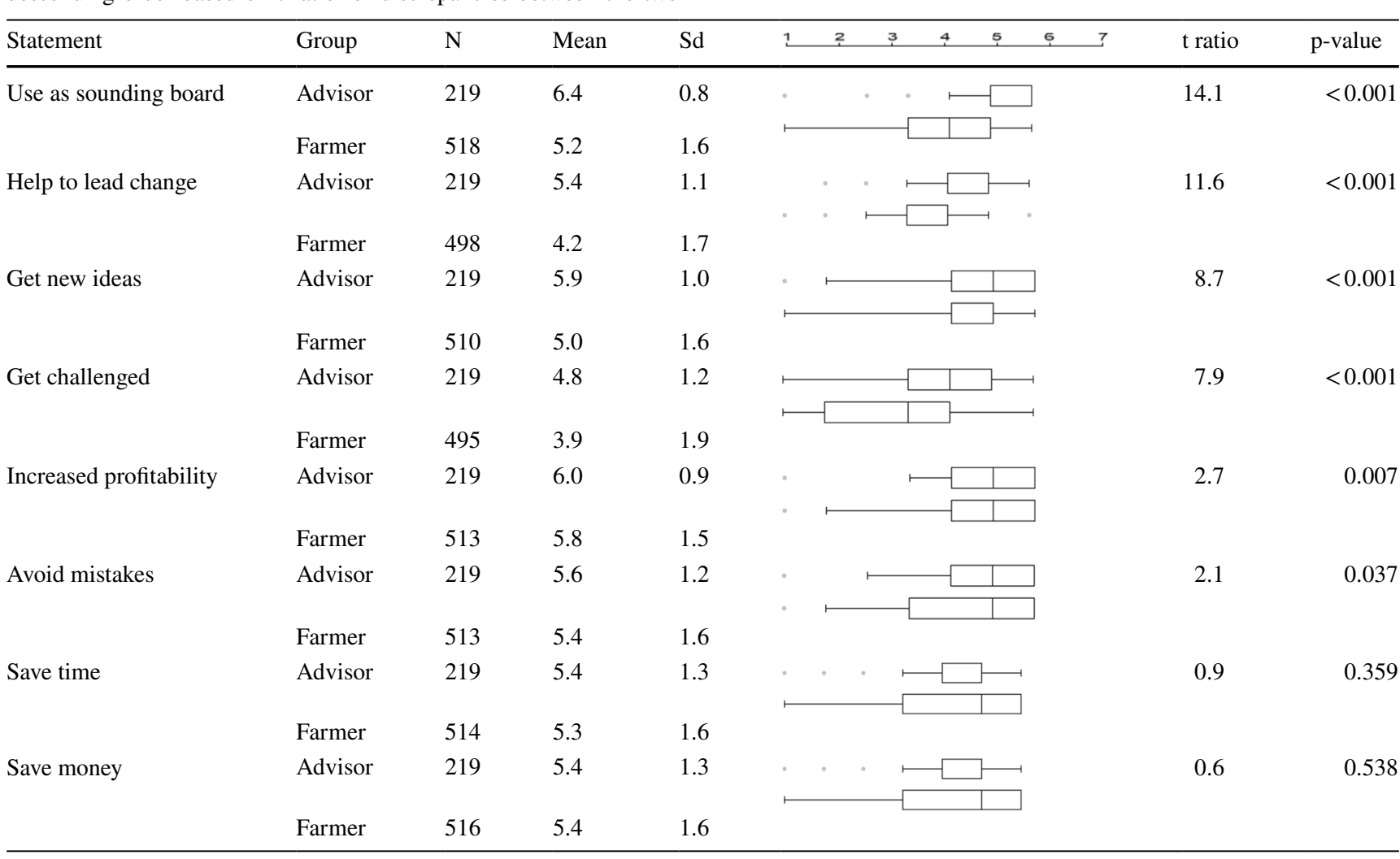

${ }^{a}$ Advisors were asked why they thought farmers chose to use advisory services, while farmers were asked why they chose to use advisory services

\section{Results and analysis}

The results from a selection of responses in the questionnaires are presented below, focusing on the similarities and discrepancies found between the two groups. The results are structured around three main themes: motives for a farmer using or not using advisory services, preferred approach by the advisor, and future demands on advisory services and their importance today. A short analysis based on the results is presented after each theme.

\section{Farmers' motives for using or not using advisory services}

Questions about the motives behind farmers' decision on using, or not using, advisory services were included in the questionnaire. The advisors were asked about what motives farmers have when using, or not using, advisory services, while the farmers were asked about the motives they have for using, or not using, advisory services.

When comparing the responses to the different statements related to motives, the greatest discrepancy between the advisors and farmers was found for 'Use as a sounding groups; boxplots with medians and quartiles illustrate the distribution of responses 
Table 4 Advisors' perceptions on farmers' motives ${ }^{\mathrm{a}}$ versus farmers' descriptions of their motives ${ }^{\mathrm{a}}$ for not choosing advisory services sorted in descending order based on t ratio for discrepancies between

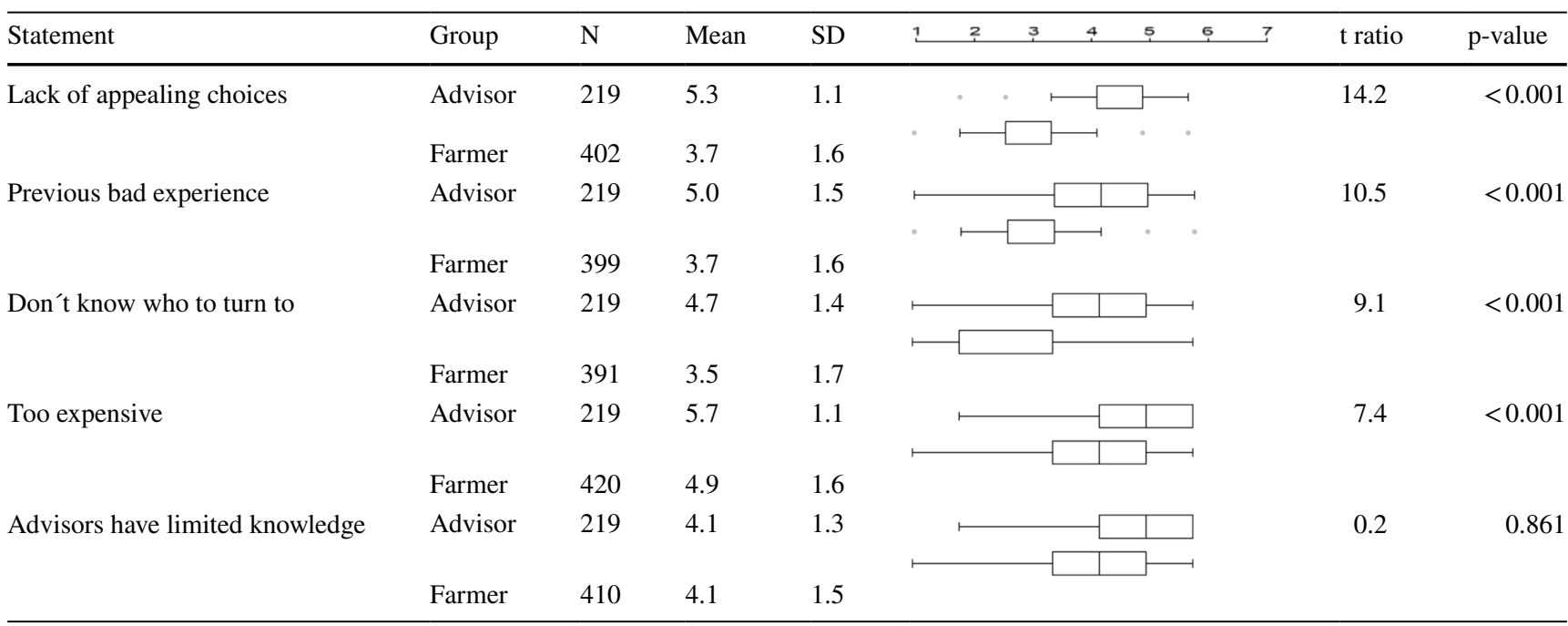

${ }^{a}$ Advisors were asked why they thought farmers chose not to use advisory services, while farmers were asked why they chose not to use advisory services

were linked to the advisor's traditional role as a specialist, where there are well defined questions and missions. All these motives ('Save money', 'Save time', 'Avoid mistakes' and 'Increase profitability') were also considered more important by the farmers, compared with the motives for which significant discrepancies were found.

The analysis within the advisor group did not show any differences based on gender, age or type of employment for any of the statements. For the analysis within the group of farmers, differences for the statements 'Get new ideas', 'Use as sounding board' and 'Get challenged' emerged. The youngest quartile of farmers, Q1, considered 'Use as sounding board' a more important motive than farmers in $\mathrm{Q} 3(\mathrm{p}=0.008)$ and $\mathrm{Q} 4(\mathrm{p}=0.001)$. A similar pattern was found for the motive 'Get challenged', where Q1 was the only group scoring it as important (mean 4.6), differing significantly $(\mathrm{p}<0.001)$ from other age groups. The statement 'Get challenged' showed differences between different types of production, with poultry, pig and arable farmers all scoring that motive as important (above 4), while the other production types did not.

Among the motives for not using advisory services, the largest discrepancy between advisors and farmers was found for 'Lack of appealing choices' $(t=14.2)$ (Table 4). The advisors considered this motive to be more important than the farmers (Table 4). The second largest discrepancy was found for the motive 'Previous bad experience' $(t=10.5)$, which was again considered to be more important by the advisors than by the farmers (Table 4). There were also significant discrepancies in the motives 'Don't know who to turn to' $(\mathrm{t}=9.1)$ and 'Too expensive' $(\mathrm{t}=7.4)$ the two groups; boxplots with medians and quartiles illustrate the distribution of responses) 
Table 5 Advisors' and farmers' perceptions on the advisor approach preferred by farmers ${ }^{\mathrm{a}}$ sorted in descending order based on $\mathrm{t}$ ratio for discrepancies; boxplots with quartiles illustrate the distribution of responses

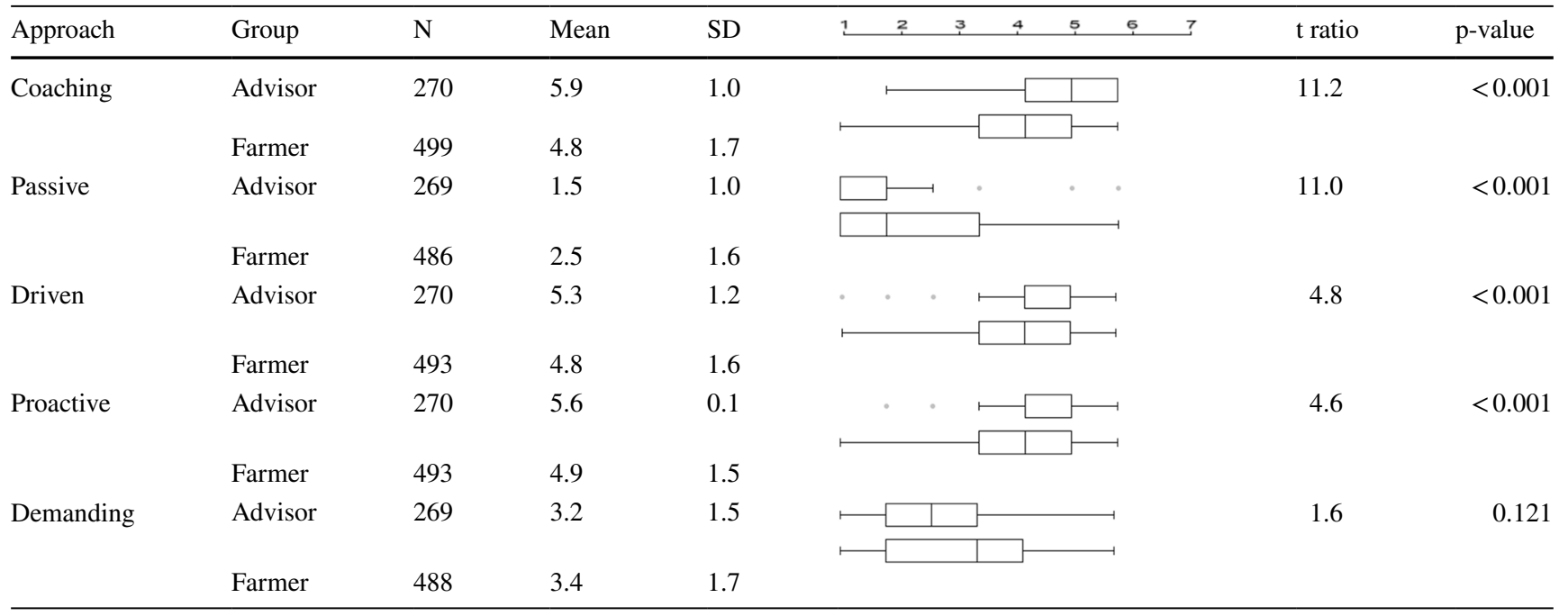

${ }^{a}$ Advisors were asked how they thought their approach was perceived and how they wanted it to be perceived, and farmers were asked what kind of approach they wanted from the advisor

were seen when comparing poultry farmers to dairy and beef farmers.

\section{Preferred approach of advisors}

When giving advice, the approach of the advisor will affect the communication with the farmer, and hence the outcome of the advice given. In the questionnaire "approach" was described as the way the advisor acts when interacting with the farmer. The advisors were asked which approach they thought farmers prefer, while farmers were asked which approach by the advisor they prefer.

The largest discrepancies between the groups were found for 'Coaching' and 'Passive' $(\mathrm{t}=11.2$ and 11.0, respectively) (Table 5). Significant discrepancies were also found for 'Driven' and 'Proactive' ( $\mathrm{t}=4.8$ and 4.6, respectively) (Table 5). The only non-significant difference between the groups was found for 'Demanding' $(\mathrm{t}=1.6)$ (Table 5).

The statements about preferred approach showed the most concordant responses between advisors and farmers among the themes. Regarding 'Coaching' and 'Demanding', the responses from both groups showed large variation, even though they represented the largest and the smallest discrepancy, respectively (Table 5). This probably means that for both advisors and farmers, these approaches are more of a personal preference than a general attitude within each group. For the other approaches listed, farmers responded across the whole scale, while the advisors were more uniform in their responses. However, the mean value for both groups was on the same side of the scale. Another interesting finding was that even though both farmers and advisors assessed 'Passive' as not wanted, the farmers were not as negative as the advisors and $25 \%$ of the farmers answered either/or (4) or above (Table 5). It is also worth noting that 'Driven' and 'Proactive' were considered more wanted than 'Help to lead change', even though a driven and proactive advisor will most likely contribute to change (Tables 3, 5).

The analysis within the advisor group showed differences based on gender. Women advisors perceived both 'Demanding' and 'Passive' as less wanted by farmers than their male colleagues ( $\mathrm{p}=0.012$ and 0.003 , respectively). No differences were found regarding age. On analysing the approach 'Driven', differences were found depending on type of employment $(\mathrm{p}=0.035)$, with advisors working at FBOs scoring it as more likely to be preferred by farmers. The analysis based on gender also showed differences within the group of farmers. The 'Passive' approach was scored as less wanted by women farmers $(p=0.027)$. There were also gender differences on the 'Coaching' approach, which women scored as more preferable than men $(p=0.042)$. When analysing the age groups, the youngest farmers, Q1, differed regarding the 'Driven' approach, scoring it as more preferable than the others. Differences depending on type of production emerged for 'Demanding'. Looking at the mean scores, sheep and beef farmers scored it as less preferred than the others (mean 2.8 and 3.1, respectively), while poultry farmers were the only respondents to score it above 4 (mean 4.1).

\section{Future demands on advisory services and their importance today}

Advisory services may target different levels of the farming business, with the focus on production, managerial 
Table 6 Discrepancies and similarities in advisors' and farmers' perceptions ${ }^{\mathrm{a}}$ on future demand for advisory services relating to different levels of the business; graphs illustrate the distribution of responses, advisors with a black line and farmers with a grey line

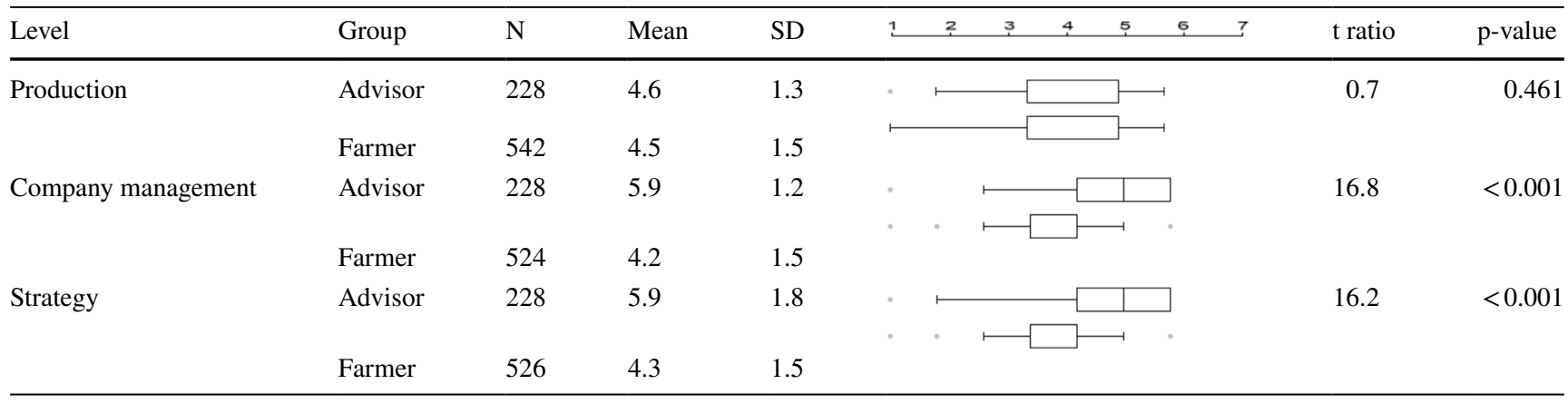

${ }^{a}$ Advisors and farmers were asked if they thought demand for advisory services directed at the production, company management and strategy would decrease (1), increase (7) or remain the same (4) in 10 years' time

(organisation, market, tactics) and strategic issues (goals and vision for the future). For this question the answer options was not on a Likert scale and thus differed from the other questions, although the alternatives were still on a scale from 1 to 7 . The advisors and farmers were asked how they expected demand for advisory services to change in 10 years' time, i.e. if demand will decrease (lowest value, 1), increase (highest value, 7) or remain as it is today (intermediate value, 4).

Regarding advisory services with the focus on the 'Production' level, the two groups were almost in total consensus $(t=0.7)$, with both expecting a slight increase (Table 6). For both 'Company management' and 'Strategy', however, there were significant discrepancies between the two groups $(\mathrm{t}=16.8$ and 16.2, respectively) (Table 6). The advisors expected increased demand for advisory services within both 'Company management' and 'Strategy', while the farmers to a great extent expected demand to remain the same (Table 6).

On analysing the answers within the advisor group on future demand for advisory services, no differences based on gender, age or type of employment were seen. Within the farmer group, there were differences depending on age and type of production, but not on gender. Concerning future demand for 'Company management', the oldest farmer group, Q4, expected a decline, while the others did not. Q4 differed significantly from Q1 $(\mathrm{p}=0.018)$ and Q2 $(p=0.006)$. Looking at the farmer group based on type of production, the beef farmers differed on all three levels, scoring lower than the farmers with other types of production.

Concerning the perceived importance of advisory services directed toward different levels of the farming business, regarding profitability and development of the farm, there were evident differences between the groups. When comparing the responses of advisors and farmers, there were significant discrepancies in the perceived importance for both profitability and development on all three levels.
The discrepancies connected to the production level were smaller than the others, and the production level was considered to be the most important by both advisors and farmers (Table 7).

Regarding the perceived importance of advisory services connected to 'Company management' and 'Strategy', the advisors assessed it as more important than the farmers for both profitability and development. Once again, the farmers showed a more heterogeneous response pattern (Table 7). However, it is worth noting that a large number of farmers chose not to answer the questions about 'Company management' and 'Strategy' (Table 7).

On analysing the differences within the groups, the advisors showed no differences depending on gender, age or type of employment for either profitability or development at any level. Farmers did not show any differences concerning gender. When analysing the farmers based on age, however, the oldest farmer group, Q4, differed significantly from Q2 $(\mathrm{p}=0.023)$ and $\mathrm{Q} 3(\mathrm{p}=0.002)$ on the perceived importance of advisory services at strategy level for farm development. Q4 scored this as not important (below 4), thus differing from all other age groups, which scored it as important. Analysing the farmers based on type of production showed differences regarding the effect of advisory services at company management level for profitability. The sheep farmers scored it as less important than all the other production types (mean 2.3), although beef and poultry farmers also perceived it as not important (mean 3.9). Dairy farmers, on the other hand, perceived it as more important than the other groups (mean 4.8).

\section{Discussion}

Analysis of the survey data identified several significant differences in advisors' and farmers' perceptions of advisory services, but there were also some areas on which there was 
Table 7 Advisors' and farmers' perceptions on the importance a of advisory services sorted in descending order based on t ratio for discrepancies; boxplots with medians and quartiles illustrate the distribution of responses

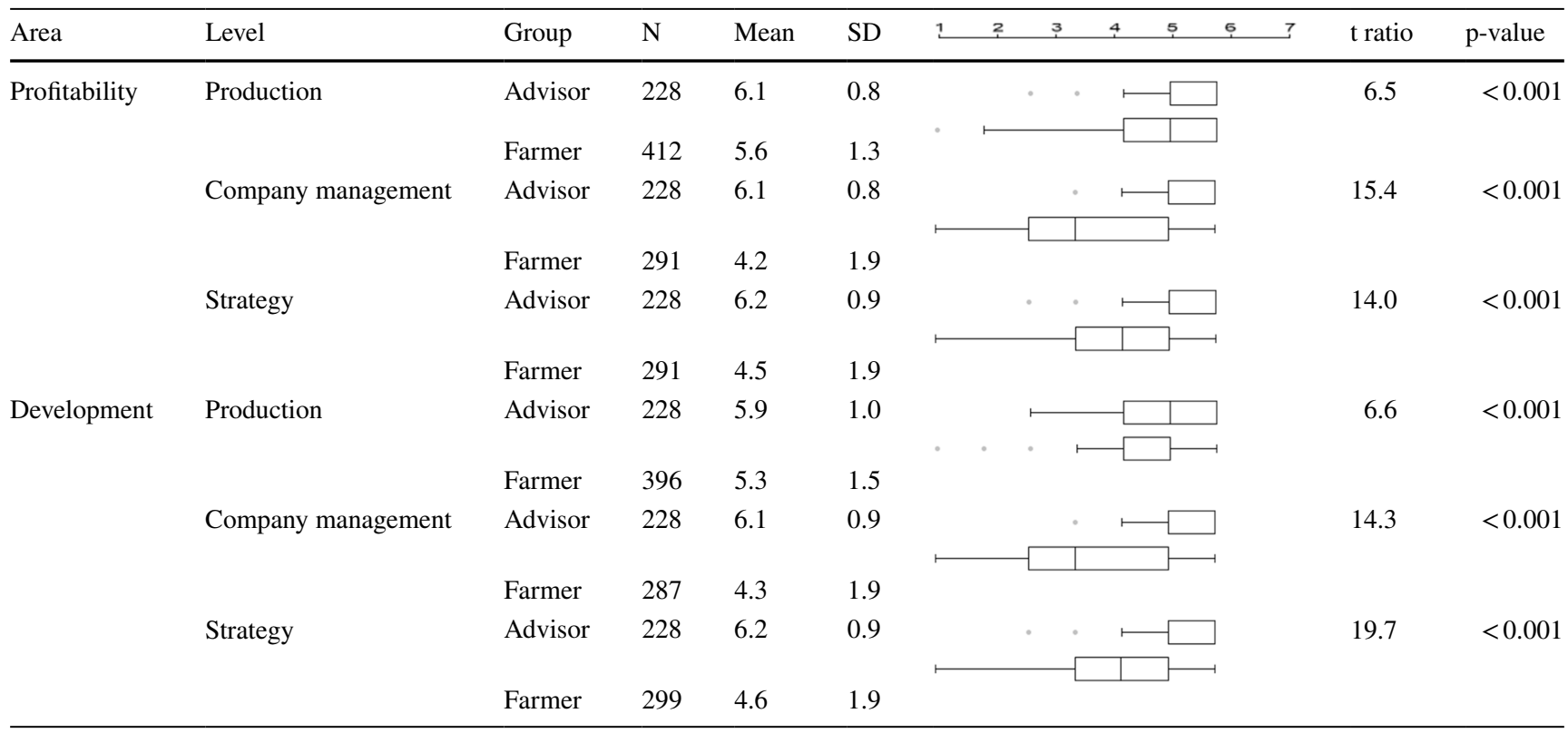

${ }^{a}$ Advisors and farmers were asked how important advisory services directed toward different levels of the business (production, company management and strategy) are for farm profitability and deve

general consensus. The survey results provide an overview of the situation for advisory services in Sweden today.

\section{Perceptions of advisory services-discrepancies and similarities}

In general, the advisors were more united in their responses than the farmers. Dwyer et al. (2007), Feder et al. (2011), McKillop et al. (2018) and Dockès et al. (2019) found similar heterogeneity in farmer groups. The uniformity of responses by the advisors could probably be explained by a combination of factors, e.g. similarity in university education, organisational in-house training and number of years of experience. The few significant differences in sociodemographic characteristics found within the advisor group were often small. The largest differences within the advisor group were based on gender, with female advisors scoring 'Demanding' and 'Passive' as less preferred by farmers than their male colleagues. It is not possible to give a well-founded explanation for these results based on the data. Generally, when analysing advisory performance as well as farmer-advisor relationship the gender aspect of advisory services often seems to be disregarded. This is an aspect to consider in future research.

The range of views within the group of farmers reflects the reality that advisors will meet in their daily work. For the advisors, the consequence of encountering the diversity of farmers might be off-target delivery in relation to farmers' expectations. To overcome this, advisors and farmers need to engage in questions about expectations on the advisory services, the individual advisor and goals for the farming business.

The socio-demographic analysis based on gender within the farmer group showed few and not highly significant differences. However, there were very few female farmers in our sample, only $9 \%$. Thus, the data are too scarce to permit a reliable discussion on differences in preferences based on gender. When analysing the farmer answers according to age, more significant differences emerged. Those in the youngest quartile (Q1, 24-47 years) were more positive to the 'Driven' approach and to using advisory services to 'Get challenged' and as a 'Sounding board'. Since Q1 represents the age range when farmers are probably elaborating on their business idea, this result is in line with expectations.

Looking at differences within the farmer group depending on type of production, a pattern reflecting the Swedish advisory system emerged. One example is the difference for 'Lack of appealing choices', which the poultry farmers scored as an important factor for not using advisory services. In the Swedish advisory system, there are no or very few choices of advisory services directed towards poultry production. Poultry farmers still spend more than many other farmers on advisory services, but probably relating to other aspects of their production. Beef and dairy farmers, on the other hand, were at the other end of the scale, scoring 'Lack of appealing choices' as unimportant. This too reflects the Swedish advisory service system, since two of the largest 
advisory organisations specialise in cattle production (beef and dairy).

The most obvious similarities between advisors' and farmers' perceptions of advisory services were found in areas characterised by defined questions or productionrelated issues. In the results, this was manifested in the motives for using advisory services, where factors such as 'Saving money', 'Saving time', 'Avoid mistakes' and 'Increased profit' were assessed as important by both advisors and farmers. Further, both groups considered advisory services directed towards the production level of the farming business to be important for farm profitability and development. The production-oriented advisory services are often characterised by discussing rather delimited issues with a here-and-now focus (Lindblom and Lundström 2014; Höckert 2017) when the questions are well-defined and the expectations on the outcome are relatively clear. In these situations, the advisor often assumes the role of specialist, which is the most common and traditional role of advisors (Ingram and Mills 2019). Related to the different loops of learning (Argyris 1976; Schön and Argyris 1996), the abovementioned aspects of advisory services can be connected to single-loop learning, which deals with incremental improvements and increasing effectiveness within the system.

The main discrepancies between the two groups as regards perceptions of advisory services were in the less concrete areas and in topics connected to change, management and strategy. These aspects can be connected to double-loop learning (Schön and Argyris 1996), which involves processes that are more questioning and reflective in nature. In the results in the present study, this was evident in the motives for using advisory services, where factors such as 'Use as sounding board', 'Help to lead change', 'Get new ideas' and 'Get challenged' showed significant differences. The farmers not only assessed these motives as less important than the advisors, but also less important than the motives for which similarities were found. However, the farmers were again heterogeneous in their responses. Further, the advisors were more positive about the importance of advisory services for profitability and development on managerial and strategic levels of the farming businesses. It was also in these areas that the largest discrepancies between the groups were found.

\section{The role of the advisor-from service provider to critical coach}

As mentioned in the introduction, farm advisors need the skill to take on different roles in their interaction with farmers, depending on the advisory situation (Andersen 2004; Klerkx and Jansen 2010; Dockès et al. 2019). The present study showed that farmers seem to prefer the traditional advisory services, where the advisor assumes the role of a specialist. In these situations, advisory delivery on target is often the case, since the mission, the expectation and the result are easy to define and communicate. It is interesting to note, however, that the advisors believed that the most important motive for farmers using advisory services is the advisor's role as a sounding board. A role as a sounding board does not exclude a role as a specialist, but it includes other functions of a more questioning and reflective character. Regarding the advisory role, it is not a question about either/or; an experienced advisor will simultaneously take on several roles in any given advisory situation.

A dimension of the specialist role, which to our knowledge has not received much attention in the literature to date, is the role of the advisor as service provider. When looking at the motives for using advisory services, 'Avoiding mistakes' and 'Saving time' were considered to be important by both advisors and farmers. In practice, these services can be exemplified by tasks performed by advisors, such as calculating feed rations, helping with applications for agri-environmental payments and supports or providing crop production plans. This provides farmers with reassurance and frees up time to spend on other things. Even though these services do not necessarily contribute to learning, development or behavioural and/or organisational change, these functions of the advisory services should not be underestimated. They contribute to building a viable business and strengthen the farmer-advisor relationship, building trust and thus laying a foundation for further development and change.

The service functions are central also for the advisory organisations, since they constitute a fundamental part of their operations. However, if the advisory organisations do not perceive themselves as service providers, but rather as important actors for development and change of the Swedish agricultural system on different scales, they will experience challenges in matching demand and supply. There will inevitably be a clash between the self-image and how the advisory organisations describe themselves, on the one hand, and the actual services they provide, on the other. This is what Schön and Argyris (1996) call a gap between espoused theories and theories-in-use (cf Höckert and Ljung 2019). The incentives for working with more complex issues, such as improving competitiveness and contributing to a sustainable farm development, will probably be marginalised as long as the advisory organisations earn a considerable part of their income by selling services, and as long as farmers appreciate and agree to pay for these services.

\section{The necessary-but challenging-change}

As noted in several Swedish government investigations and policy documents, there is a common view that farmers in general need to become more business-oriented and that advisors have a vital role to play in supporting this 
process (SOU 2014:38; OECD 2018; SLU 2018; Gielen and Nyström 2019). As seen from the results obtained in the present study, advisors have grasped this need to a great extent (Table 6), but farmers do not regard advisors as their support in change on these issues. However, it is not possible from our empirical material to conclude whether Swedish farmers see a need for developing their business. It is obvious that previous efforts by different actors in the advisory system to make farmers more business-oriented (cf Höckert and Ljung 2013) have not affected farmers' perceived need for advisory services connected to management and strategy to any greater extent.

The large proportion of farmers who chose not to respond to the questions about their perceptions on advisory services related to company management and strategy (compared with the number who answered the questions related to production issues) can be seen as an expression of uncertainty among farmers about how the advisory organisations could help them in these matters. Consequently, if advisors are to take on the role suggested by policymakers, they need to involve farmers in discussions about the future, help them see the benefit of strategic and managerial improvement and encourage them to regard advisors as trustworthy support in this process. As Dockès et al. (2019) notes, however, development work requires long-term commitment from all actors involved.

\section{Methodological reflections}

Data obtained through questionnaires have their limitations. The questionnaire method is suitable when looking to draw a general picture, but it will not deliver the nuances or reveal the full extent of the issue under study. The greatest risk with questionnaires is restriction, whereby the analyst forces subjects into certain reactions (Alvesson and Sköldberg 2018). In many of the areas analysed in the present study, it was not a question of either/or. Rather the response depended on the situation, an aspect which is not possible to capture in a questionnaire.

Our results might also have been affected by the fact that one of the larger advisory organisations in Sweden declined to participate. Their services are mainly of an economic nature and on issues such as accounting and balancing of books, but they also have a few business management advisors. However, this study focused on advisory services, and not the specialisation of the advisors.

\section{Implications for advisory services}

In this final section, the implications of the survey results and the themes discussed above are assessed in relation to the impact they may have on the advisory organisations and the services they provide. The first part of the assessment focuses on the issues that influence on-farm service delivery, while the second part focuses on how these issues could be improved on individual and organisational level. The third and final part discusses the need for a strong back-office in order to meet the challenges in an ever-changing world.

\section{The risk of off-target delivery}

As stated several times in this paper, the distribution of responses provided by the farmers was rather heterogeneous throughout the questionnaire. In practice, this meant that within the group of farmers surveyed, the whole range of opinions was often represented in the themes identified in the survey responses. When an advisor meets a farmer in an advisory situation, there is hence an obvious risk of offtarget delivery (including delivering too much or too little), especially if/when the expectations and goals of the planned advisory activity are not clearly expressed.

When a farmer decides to use advisory services, it is often with regard to a rather specific question or a service needed. Despite that, the delivery by advisors will probably vary. Although the question and/or service may be rather well-defined, an answer can often be given on several levels. Depending on the advisor's experience, their observational skill (Bardes et al. 2001), i.e. their skill for seeing beyond the spoken word, will vary in each specific case. Advisors with limited experience or who are insecure or overly ambitious might want to provide as many answers and services to farmers as possible. While this delivery will be what some farmers need and expect, it will be perceived as over-delivery by others. In cases where the purpose of the advisory service is more vague in character, e.g. on managerial or strategic issues, the risk of off-target delivery is probably even greater.

The issue of delivering more than the farmer has "asked" for (although not explicitly) is of course not only negative for the farmer, but also for the advisory organisation. The farmer may perceive the service as too time-consuming, not in line with their own expectations and/or too costly, which risks negatively affecting their attitude to advisory services in general. An over-delivering advisor is also costly from an organisational perspective, since the issue of making advisors charge for their actual services will probably be a problem.

\section{Improvements on individual and organisational level}

The risk of delivering an off-target advisory service in encounters with farmers can of course be reduced by taking measures on both individual and organisational level, or in other terminology, at front-office and back-office level 
(Labarthe and Laurent 2013). These measures should not be considered to be either-or, but rather two sides of the same coin that support and strengthen each other. Entering a dialogue with a somewhat altered perspective can only be achieved by the individual advisor. In the interaction with each farmer, the advisor has to form an opinion of the (actual) advisory need, depending on the situation or the phase that the farming business is in at present. The easiest way for an advisor to deliver services according to the customer's needs and expectations is of course by engaging in dialogue about those issues. However, if agriculture is to develop in accordance with policy visions (cf OECD 2018; EU SCAR 2012, 2019), while coping with ongoing global trends in advisory services such as deregulation and privatisation (Fielke et al. 2020), advisors will need to engage in dialogue that goes beyond the production-optimising services characterised by single-loop learning and also engage in double-loop learning on issues at managerial and strategic levels. Schön and Argyris (1996) argue that double-loop learning is necessary if practitioners and organisations are to make informed decisions in rapidly changing and often uncertain contexts.

The observational skill to discern (followed by addressing and acting upon) actual need, and not be content with delivering answers to easily articulated matters, takes time to develop. However, it is worth noting that the skill will not arise by itself through years of experience alone and that training is needed. The challenge for the advisory organisations is to create a back-office that offers a conducive environment for their advisors. In practice, this means helping advisors develop the necessary skills and giving them the agency to take on new roles (cf Landini et al. 2017; Nettle et al. 2018), as well as offering organisational structures that support collaboration between advisors with different types of expertise, in order to better meet the challenges faced by agriculture.

\section{The importance of a strong back-office in disruptive times}

As shown in this study, there is a gap between farmers and advisors in terms of perceived future demands and perceived importance of managerial and strategic advisory services, two aspects of advisory services identified in policy as key for coping with ongoing challenges in agriculture (SOU 2015:15; OECD 2018; Gielen and Nyström 2019). This gap can be seen as a manifestation of the challenge for innovation of new services in a demand-driven advisory system (cf. Fielke et al. 2020). As regards production-related advisory services, the privatised market-which is the reality in many countries where governments have shifted the responsibility for advisory services to the private sector-is seemingly well-synchronised with the demands expressed by farmers.
However, when it comes to managerial and strategic advisory services, the private system can be described as supplydriven. The question is of course how to respond when the perceived responsibility of advisors do not correspond to the stated demands of customers. Given the disruptive period that agriculture is experiencing, an ability to look beyond expressed demands and understand customers' unspoken needs will probably become increasingly important. However, developing new services will require access to risk capital, which is far from the economic reality faced by many Swedish advisory organisations (cf. SLU 2018; Gielen and Nyström 2019). The consequence of advisory organisations having weak back-office activities (Labarthe and Laurent 2013) is of course that, although advisors may be competent in their interaction with their customers (front-office activities), the long-term ability to deliver high-quality services will be eroded. This in turn will lower the competitiveness of farming, as new business opportunities may be overlooked. To avoid this critical situation, it is of the utmost importance that advisory organisations themselves can bear the cost of continuous development of new services and existing competences.

Acknowledgements The authors would like to thank Jan-Eric Englund for contribution with statistical expertise.

Funding Open access funding provided by Swedish University of Agricultural Sciences.

Open Access This article is licensed under a Creative Commons Attribution 4.0 International License, which permits use, sharing, adaptation, distribution and reproduction in any medium or format, as long as you give appropriate credit to the original author(s) and the source, provide a link to the Creative Commons licence, and indicate if changes were made. The images or other third party material in this article are included in the article's Creative Commons licence, unless indicated otherwise in a credit line to the material. If material is not included in the article's Creative Commons licence and your intended use is not permitted by statutory regulation or exceeds the permitted use, you will need to obtain permission directly from the copyright holder. To view a copy of this licence, visit http://creativecommons.org/licenses/by/4.0/.

\section{References}

Alvesson, M., and K. Sköldberg. 2018. Reflexive methodology: New vistas for qualitative research, 3rd ed. Thousand Oaks, CA: SAGE Publications Inc.

Andersen, H.J. 2004. Different personal skills and competencies which local agricultural advisers can use to co-create change in management procedures: A case-study of Danish dairy farmers and advisers. The Journal of Agricultural Education and Extension 10 (4): $151-162$.

Argyris, C. 1976. Single-loop and double-loop models in research on decision making. Administrative Science Quarterly 21 (3): 363-375. 
Bardes, C.L., D. Gillers, and A.E. Herman. 2001. Learning to look: Developing clinical observational skills at an art museum. Medical Education 35 (12): 1157-1161.

Birner, R., K. Davis, J. Pender, E. Nkonya, P. Anandajayasekeram, J. Ekboir, A. Mbabu, D.J. Spielman, D. Horna, and S. Benin. 2009. From best practice to best fit: A framework for designing and analyzing pluralistic agricultural advisory services worldwide. Journal of Agricultural Education and Extension 15 (4): 341-355.

Blackmore, C. 2010. Social learning systems and communities of practice. London, UK: Springer.

Blackstock, K.L., J. Ingram, R. Burton, K.M. Brown, and B. Slee. 2010. Understanding and influencing behaviour change by farmers to improve water quality. Science of the Total Environment 408 (23): 5631-5638.

Burton, R.J.F. 2004. Seeing through the 'good farmer's' eyes: Towards developing an understanding of the social symbolic value of 'productivist' behaviour. Sociologia Ruralis 44 (2): 195-215.

Collins, A.L., Y.S. Zhang, M. Winter, A. Inman, J.I. Jones, P.J. Johnes, W. Cleasby, E. Vrain, A. Lovett, and L. Noble. 2016. Tackling agricultural diffuse pollution: What might uptake of farmer-preferred measures deliver for emissions to water and air? Science of the Total Environment 547: 269-281.

Dockès, A.-C., S. Chauvat, P. Correa, A. Turlot, and R. Nettle. 2019. Advice and advisory roles about work on farms: A review. Agronomy for Sustainable Development 39 (1): 2.

Dwyer, J., J. Mills, J. Ingram, J. Taylor, R. Burton, K. Blackstock, B. Slee, K. Brown, G. Schwarz, and K. Matthews. 2007. Understanding and influencing positive behaviour change in farmers and land managers. Gloucester: CCRI, Macaulay Institute.

EU SCAR, AKIS. 2012. Agricultural knowledge and innovation systems in transition: A reflection paper. Brussels: European Commission.

Faure, G., Y. Desjeux, and P. Gasselin. 2012. New challenges in agricultural advisory services from a research perspective: A literature review, synthesis and research agenda. The Journal of Agricultural Education and Extension 18 (5): 461-492.

Feder, G., R. Birner, and J.R. Anderson. 2011. The private sector's role in agricultural extension systems: Potential and limitations. Journal of Agribusiness in Developing and Emerging Economies 1: 31.

Fielke, S., B. Taylor, and E. Jakku. 2020. Digitalisation of agricultural knowledge and advice networks: A state-of-the-art review. Agricultural Systems 180: 102763.

Gielen, K., and M. Nyström. 2019. Nationell kunskapsförsörjning för en hållbar och konkurrenskraftig animaliesektor. Rapport, vol. 2019:4. Jönköping: Jordbruksverket.

Hajdu, F., C. Eriksson, C. Waldenström and E. Westholm. 2020. Sveriges förändrade lantbruk - Lantbrukarnas egna röster om förändringar sedan 1990-talet och strategier inför framtiden. SLU Future Food Reports 11: Sveriges lantbruksuniversitet, forskningsplattformen SLU Future Food.

Höckert, J. 2017. Sharing lifeworlds and creating collaborative cultures. Ph.D. dissertation. Department of Rural and Urban Development. Swedish University of Agricultural Sciences, SLU, Uppsala.

Höckert, J., and M. Ljung. 2013. Advisory encounters towards a sustainable farm development-Interaction between systems and shared lifeworlds. The Journal of Agricultural Education and Extension 19 (3): 291-309.

Höckert, J., and M. Ljung. 2019. Organisational cultures and epistemology as barriers between vision and practice in advisory organisations in Sweden. Paper presented at the 24th European Seminar on Extension (and) Education, Acireale, Italy, 18-21 June

Ingram, J. 2008. Agronomist-farmer knowledge encounters: An analysis of knowledge exchange in the context of best management practices in England. Agriculture and Human Values 25 (3): 405-418. https://doi.org/10.1007/s10460-008-9134-0.
Ingram, J., and J. Mills. 2019. Are advisory services "fit for purpose" to support sustainable soil management? An assessment of advice in Europe. Soil Use and Management 35 (1): 21-31.

Ingram, J., P. Gaskell, J. Mills, and C. Short. 2013. Incorporating agrienvironment schemes into farm development pathways: A temporal analysis of farmer motivations. Land Use Policy 31: 267-279.

Inman, A., M. Winter, R. Wheeler, E. Vrain, A. Lovett, A. Collins, I. Jones, P. Johnes, and W. Cleasby. 2018. An exploration of individual, social and material factors influencing water pollution mitigation behaviours within the farming community. Land Use Policy 70: 16-26.

Kania, J., K. Vinohradnik and A. Knierim. 2014. AKIS in the EU: The inventory-Final Report. PRO AKIS-Prospects for Farmers' Support: 'Advisory Services in the European AKIS, vol. 1. Krakow, Poland.

Klerkx, L., and J. Jansen. 2010. Building knowledge systems for sustainable agriculture: Supporting private advisors to adequately address sustainable farm management in regular service contacts. International Journal of Agricultural Sustainability 8 (3): 148163. https://doi.org/10.3763/ijas.2009.0457.

Knierim, A., P. Labarthe, C. Laurent, K. Prager, J. Kania, L. Madureira, and T. Hycenth Ndah. 2017. Pluralism of agricultural advisory service providers-Facts and insights from Europe. Journal of Rural Studies 55: 45-58.

Labarthe, P., and C. Laurent. 2013. The importance of the back-office for farm advisory services. EuroChoices 12 (1): 21-26.

Landini, F. 2016. How to be a good rural extensionist. Reflections and contributions of Argentine practitioners. Journal of Rural Studies 43: 193-202.

Landini, F., W. Brites, and M.I. Mathot y Rebolé. 2017. Towards a new paradigm for rural extensionists' in-service training. Journal of Rural Studies 51: 158-167.

Lindblom, J., and C. Lundström. 2014. Lantbrukares beslutsfattande och lantbruksrådgivning: en förstudie (DEMIPROF). Uppsala: Sveriges Lantbruksuniversitet.

Malhotra, N.K. 2006. Questionnaire design and scale development. In The handbook of marketing research: Uses, misuses, and future advances, ed. R. Grover and M. Vriens, 83-94. Thousand Oaks: Sage.

McKillop, J., K. Heanue, and J. Kinsella. 2018. Are all young farmers the same? An exploratory analysis of on-farm innovation on dairy and drystock farms in the Republic of Ireland. The Journal of Agricultural Education and Extension 24 (2): 137-151. https://doi.org/10.1080/1389224X.2018.1432494.

Melin, M., and H. Barth. 2018. Lean in Swedish agriculture: Strategic and operational perspectives. Production Planning \& Control 29 (10): 845-855.

Mills, J., P. Gaskell, J. Ingram, J. Dwyer, M. Reed, and C. Short. 2017. Engaging farmers in environmental management through a better understanding of behaviour. Agriculture and Human Values 34 (2): 283-299.

Nettle, R., A. Crawford, and P. Brightling. 2018. How private-sector farm advisors change their practices: An Australian case study. Journal of Rural Studies 58: 20-27.

Nordlund, I. and T. Norrby. 2021. AKIS and advisory in Sweden. Report for the AKIS inventory (Task 1.3) of the i2connect project.

OECD. 2018. Innovation, agricultural productivity and sustainability in Sweden. OECD Food and Agricultural Reviews. Paris: OECD Publishing.

Prager, K., R. Creaney, and A. Lorenzo-Arribas. 2017. Criteria for a system level evaluation of farm advisory services. Land Use Policy 61: 86-98.

Röling, N., and J.N. Pretty. 1997. Extension's role in sustainable agricultural development. In Improving agricultural extension: 
A reference manual, ed. B.E. Swanson, R.P. Bentz, and A.J. Sofranko, 181-191. Rome: FAO.

Scar, E.U., and AKIS. . 2019. Preparing for future AKIS in Europe. Brussels: European Commission.

Schön, D., and C. Argyris. 1996. Organizational learning II: Theory, method and practice, vol. 2, 305. Reading: Addison Wesley.

SJV. 2018. Holdings in the Farm register and Business Register. Classification, employed in agriculture holdings and other gainful activities 2016. Sveriges Officiella Statistik - Statistiska Meddelanden JO 34 SM 1801. Stockholm: Statiscs Sweden.

SLU. 2018. Rapport om uppdraget att, inom ramen för livsmedelsstrategin, utveckla samverkan och samverkansformer mellan forskning och rådgivning (N2017/04769/JM). Uppsala: SLU.

SOU. 2014:38. Tillväxt och värdeskapande-Konkurrenskraft i svenskt jordbruk och trädgårdsnäring. Delbetänkande av Konkurrenskraftsutredningen. Stockholm: Elanders Sverige AB.

SOU. 2015:15. Attraktiv, innovativ och hållbar-Strategi för en konkurrenskraftig jordbruks-och trädgårdsnäring. Slutbetänkande av Konkurrenskraftsutredningen. Stockholm: Elanders Sverige AB.

Wästfelt, A., and C. Eriksson. 2017. Det svenska lantbrukets omvandling 1990-2014: Exemplet Uppsala län. Uppsala: Sveriges Lantbruksuniversitet.

Yngwe, K. 2014. Agricultural Knowledge and Information Systems in Sweden. Report for the AKIS inventory (WP3) of the PRO AKIS project.

Publisher's Note Springer Nature remains neutral with regard to jurisdictional claims in published maps and institutional affiliations.

Jannica Krafft is an Industry Ph.D. Candidate at Department of People and Society, Swedish University of Agricultural Sciences (SLU), Alnarp, Sweden. Beside her studies she works as a production advisor for dairy and beef farmers at Växa Sverige in Falkenberg. Her Ph.D. project focuses on advisory services in Sweden.

Jenny Höckert Agr.D./Ph.D., is a researcher at National Competence Centre for Advisory Services, Department of People and Society, Business Economics and Environmental Psychology, Swedish University of Agricultural Sciences (SLU), Skara, Sweden. Jenny is interested in how agricultural advisory services could better support a sustainable farm development.

Magnus Ljung Agr.D./Ph.D., senior researcher at National Competence Centre for Advisory Services, Department of People and Society, Swedish University of Agricultural Sciences (SLU), Skara, Sweden. $\mathrm{He}$ is a research leader related to agricultural extension and advisory services in natural resource management. The common thread being to better understand social and institutional innovations as well as the learning and communicative dimension of agricultural and rural development and natural resource management. Deputy supervisor for several $\mathrm{PhD}$-students and opponent on academic dissertations.

Sara Lundberg M.Sc., is a regional manager at Växa Sverige. Her main responsibility is to support the development of advisory services directed toward arable farming and animal housing at Växa Sverige.

Christina Lunner Kolstrup is associate professor and head of department at the Department of People and Society, Swedish University of Agricultural Sciences (SLU), Alnarp, Sweden. Besides her research she teaches and supervise students at bachelor, master and Ph.D. level in occupational health and safety, social sustainability and agroecology in rural, urban and agricultural settings. Her research has mainly been focused on work and safety in agriculture. 